Mika Holopainen ja Sirkka-Liisa Korkeila

\title{
KIRJASTOT JA TIETOPALVELUT MUUTOKSESSA: VERKKOVIESTINTÄÄ JA HUOLTA TULEVAISUUDESTA
}

Yhteiskunnallisen tiedon kirjastoverkosto järjesti toukokuussa työpajan, jossa koottiin tietoja kirjastoissa viime vuosina tapah-

tuneista muutoksista sekä organisaatioiden että kirjastotyön näkökulmasta. Työpajassa nousi esiin suuret muutokset sekä työn painottuminen verkkoviestintään yhä vahvemmin. Vertasimme työpajan tuloksia keväällä 2019 toteutettuun varsin laajaan kirjastoalan kyselyyn ja havaitsimme, että kyselyn tulokset olivat samansuuntaisia: $72 \%$ vastaajista oli huolissaan kirjastoalan tulevaisuudesta.

Y hteiskunnallisen tiedon kirjastoverkosto järjesti 9.5.20I9 työpajan otsikolla Kirjastot ja tietopalvelut muutoksessa Patentti- ja rekisterihallituksen tiloissa. Työpajan osallistujat edustivat kymmentä eri organisaatiota ja kolmea kirjastosektoria: erikoiskirjastoja, yliopistokirjastoja ja ammattikorkeakoulukirjastoja. Mukana oli myös osallistujia yksiköistä, joiden toiminta painottuu tietopalvelu- tai arkistotyöhön.

Lähtökohtana työpajassa oli viisi teemaa: I) Organisaation muutokset 2) asiakas- ja tietopalvelun muutokset sekä asiaan liittyvät tietosuojakysymykset 3) viestintä ja markkinointi 4) kouluttautuminen ja osaamisen kehittäminen sekä 5) uudet palvelut ja toiminnot.

Tässä artikkelissa vertailukohtana oleva kysely on Suomen kirjastoseuran ja kirjastoalan ammattijärjestöjen Minerva-ryhmän toteuttama kevälllä
2019. Kyselyyn on vastannut yhteensä I686 kirjastoalan ammattilaista.

Organisaatiomuutoksia ja ytneuvotteluja

Monissa kirjastoissa tai niiden kehysorganisaatioissa on tehty laajamittaisia organisaatiomuutoksia, joiden vaikutukset kirjastojen toimintaan ja palveluihin ovat vaihdelleet. Organisaatiomuutos on voinut aiheuttaa esimerkiksi kirjaston yhdistämisen organisaation toiseen yksikköön. Toisaalta kirjaston koko organisaatio on voitu uudistaa osana laajempaa fuusiota, jossa useita organisaatioita ja niiden kirjastoja on yhdistetty.

Useiden kirjastojen kehysorganisaatiossa on käyty viime vuosien aikana vähintään yhdet yt-neuvottelut, joiden seurauksena kirjaston tai tietopalvelun henkilöstöresurssit ovat vähentyneet irtisanomisten, osa-aikaistamisten tai 
henkilöstön muihin yksiköihin sijoittamisen johdosta. Henkilöstöresurssia on toisaalta voitu jakaa siten, että osa henkilöstöstä toimii kirjaston lisäksi jossain muussa yksikössä. Henkilöstöresurssien vähenemiseen on vaikuttanut useissa organisaatiossa myös se, että eläköityneiden tai muuten poislähteneiden tilalle on rekrytoitu uutta henkilöstöä vain poikkeustapauksissa.

Syynä henkilöstön vähennyksiin ovat pääasiassa kehysorganisaatioiden rahoituksessa tapahtuneet heikennykset. Kirjastojen osalta budjetteja on monissa tapauksissa leikattu useina perättäisinä vuosina. Lisäksi tilavuokrien nousu ja e-aineistosopimuksiin liittyvät jatkuvat hinnankorotukset ovat ajaneet etenkin korkeakoulukirjastoja ahtaalle.

Organisaatiomuutokset ja henkilöstön väheneminen on aiheuttanut tehtävien uudelleenorganisointia ja usein merkittäviä muutoksia henkilöstön työnkuvissa. Yliopistokirjastoissa tutkimuspalvelut ovat saaneet tärkeän roolin. Joissakin kirjastoissa ja tietopalveluissa muutokset ovat vaikuttaneet siten, että haasteena henkilöstöllä on oman aseman säilyttäminen kehysorganisaatiossa. Tämä edellyttää oman työn ja asiantuntijuuden näkyväksi tekemistä eri tavoin.

Yt-neuvottelut ja kiristynyt budjettitilanne ovat tuoneet moniin kir- jastoihin pysyvän varovaisuuden ja epävarmuuden ilmapiirin. Kirjaston henkilöstön leikkaukset ovat aiheuttaneet etenkin pienissä kirjastoissa monenlaisia paineita, jolloin esimerkiksi uuden kirjastojärjestelmän hankintaan ja käyttöönottoon liittyvä lisätyö voi olla hyvin haastavaa.

\section{Palveluaikojen supistamista ja itsepalvelua}

Monen kirjaston asiakaspalvelussa näkyy resurssien väheneminen palveluaikojen supistamisena. Useissa kirjastoissa on otettu käyttöön omatoimikirjastoksi kutsuttu formaatti, jolloin asiakkaat toimivat palveluaikojen ulkopuolella itsepalveluperiaatteella.

Fyysisen asiakaspalvelun lisäksi kirjastot palvelevat yhä enemmän verkossa. Sähköpostin rinnalla chat-palvelut ovat yleistyneet, ja chatin kautta tulevien kysymysten märät ovat kasvussa.

Kaikilla kirjastosektoreilla oli kokemuksia tietopalvelukysymysten vaikeutumisesta. Asiakkaat osaavat hakea tietoa itse, mutta monimutkaisempiin asioihin kaivataan apua. Tämä tuo haasteita kirjastoväen ammattitaidolle, kun tiedonhaku vaatii rinnalle haetun tiedon substanssin ymmärtämistä. Tietopalvelun vaikeutumisesta huolimatta asiakkaiden tiedontarpeisiin pyritään 
löytämään vastauksia. Verkostoitumisen koettiin helpottavan yhteydenpitoa muihin kirjastoihin ja asiakkaiden ohjaamista näihin.

Tietosuojan osalta lainsäädäntö ja organisaation omat käytännöt ovat tuoneet monenlaisia muutoksia, kuten rekisteriselosteiden laatimista, lomakkeiden siirtämistä lukittaviin kaappeihin, asiakastietojen poistamista määräajan kuluttua ja lomakkeiden silppuamista käsittelyn jälkeen.

\section{Viestinnän resursseissa ja välineissä paljon vaihtelua}

V erkoston työpajassa pohdittiin edelleen, millaisia muutoksia kirjastojen viestinnässä ja markkinoinnissa on tapahtunut sekä millaisia uusia välineitä tai menetelmiä on otettu käyttöön viime vuosina.

Työpajassa huomattiin, että viestintää ja markkinointia hoidetaan kirjastoissa hyvin moninaisin tavoin. Paljon riippuu kirjaston koosta ja asiakaskunnasta. Pienissä kirjastoissa viestintään on yleensä niukasti resursseja, kun taas isommissa kirjastoissa tai niiden kehysorganisaatioissa on jopa omat viestintätiimit, jotka hoitavat valtaosan asiakasviestinnästä.

Keskeinen viestinnän kanava on kirjaston omat palvelusivut ja verkkokirjasto. Monilla kirjastoilla on lisäksi blogeja, joissa markkinoidaan palveluja ja kerrotaan tärkeistä asioista. Myös sähköpostilla lähetettävät uutiskirjeet ja organisaatioiden intranetin keskusteluyhteisöt tai tiedotteet ovat viestin- nässä hyödynnettyjä kanavia.

Reaaliaikainen viestintä asiakkaiden kanssa chatin välityksellä on viime vuosina yleistynyt erityisesti korkeakoulukirjastoissa. Sen sijaan sähköpostin käyttö asiakasviestinnässä on monissa organisaatioissa vähentynyt viime vuosina.

Korkeakoulukirjastot ja monet erikoiskirjastotkin viestivät aktiivisesti erityisesti Facebookin ja Twitterin välityksellä. Laadukkaiden markkinointivideoiden tuottamiseen on kirjastoissa kiinnostusta mutta ei välttämättä osaamista.

Monissa kirjastoissa järjestetään aineistoihin ja palveluihin liittyviä tapahtumia tai osallistutaan kehysorganisaation tapahtumien järjestämiseen. Tähän toimintaan toivottiin työpajassa enemmän resursseja. Erilaisia pop up -tapahtumia ovat järjestäneet erityisesti korkeakoulukirjastot, mutta myös valtionhallinnossa on kokeiltu vastaavaa menestyksekkäästi.

Erikoiskirjastoissa haasteena on tunnettavuus ja uusien asiakkaiden tavoittaminen. Miten saadaan levitettyä tietoa kirjaston olemassaolosta ja palveluista potentiaalisille tiedon tarvitsijoille?

\section{Kirjastoala on oppimismyönteinen}

Kirjastoissa yleisesti kannustetaan kouluttautumiseen. Osaamisen kehittämisvaatimuksissa tulevat joskus kuitenkin taloudellisten resurssien rajoitteet vastaan, pienissä kirjastoissa myös työre- 


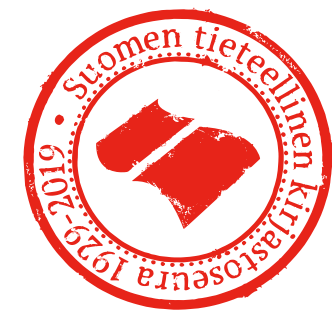

surssit, kun koulutukseen on hankalaa irrottautua asiakaspalvelun kärsimättä. Joissakin kirjastoissa on kansainvälisiin konferensseihin osallistumisia vähennetty reilusti. Toisaalta verkkokurssit ja webinaarit ovat helpottaneet koulutuksiin pääsyä.

Työpajassa esitettiin erilaisia tapoja, joilla joidenkin organisaatioiden johto kannustaa henkilöstöä kouluttautumiseen:

- Koulutukseen saa käyttää kymmenen työpäivää vuodessa.

- Lupa kouluttautua työajalla yksi tunti viikossa.

- Koulutustarpeet kartoitetaan kehityskeskusteluissa.

- Laaditaan osaamiskartoitus, jonka avulla kullekin luodaan opintopolku.

\section{Opintopiirit ja muut}

\section{vertaisoppimisen tavat}

Verkoston työpajassa osaamisen kehittämistä pohdittaessa esitettiin kirjastoissa käytettyjä vertaisoppimisen tapoja. Tiimit tai työntekijät voivat esimerkiksi opetella yhdessä uusia asioita tai kouluttajana voi toimia aiheeseen perehtynyt työtoveri, teemana vaikkapa tietokannan käytön kertaus.

Joissakin kirjastoissa toimii opintopiirejä. Nämä suorittavat yhdessä kursseja tai tutustuvat johonkin aiheeseen, niin että kukin opintopiirin osallistujista alustaa jostain osiosta ja lopuksi aiheesta keskustellaan.

Monen työpajaan osallistuneen kirjastossa on säännöllisiä oppimis- tuokioita, joissain varttitunnin, joissain aamupäivän mittaisia, jolloin joku kertoo vaikkapa uudesta palvelusta, kurssista jolla on käynyt tai muutoin oppimansa hyödyllisen asian. Tiedon jakamista työtovereiden kesken pidetään olennaisena oppimisen tapana. Pienille kirjastoille verkostot ovat tässä tarpeellisia.

\section{Osaamisen kehittäminen - mihin suuntaan?}

"Digijuttujen" ja työvälineiden lisäksi asiasisältöjen hallinnan kehittämiseen on tarvetta. Varsinkin yliopistokirjastoissa korostuu tehtäviin liittyvä erikoisosaaminen, esimerkiksi datan tai e-aineistojen hallintaan liittyvän osaamisen lisääminen.

Kuitenkin on vaikeaa arvioida, millaisella osaamisella pärjäämme tulevaisuudessa. Työpajan osallistujat totesivat, että kaikkeen siihen osaamiseen, jota kirjastoalan työpaikkailmoituksissa jo nyt vaaditaan, ei ole olemassa yksittäistä kurssia tai koulutusta. Jatkuva kouluttautuminen ja työssäoppiminen ovat siten välttämättömiä.

\section{Uusia palveluja sekä uusia ajattelumalleja}

Kirjastot ovat ottaneet aktiivisesti käyttöön erilaisia uusia palveluja. Työpajassa käytiin läpi joitakin niistä.

Aineistojen ja niiden esilletuomisen kannalta ovat e-aineistoihin liittyvät uudet toimintatavat nousseet tärkeiksi. 
Pienemmissä kirjastoissa on esimerkiksi osin siirrytty tilatuista kausijulkaisuista yksittäisten artikkelien ostamiseen. Painetun kokoelman esille nostosta hieno malli on Nuorisotiedon kirjaston Laukkukirjasto, joka jalkautuu kirjat mukanaan erilaisiin tapahtumiin.

Avoimen tieteen ja datanhallinnan palvelut, ja niiden kehittäminen, ovat yliopisto- ja amk-kirjastoissa merkittävässä roolissa. Uudentyyppisiä palveluita ovat näkyvyys- ja altmetriikkapalvelut, joita on otettu käyttöön yliopistokirjastoissa. Myös tekoälyä on alettu hyödyntää avointen verkkoaineistojen seurannassa.

Muita uusia avauksia kirjastojen ja tietopalvelujen palveluvalikoimassa ovat muiden muassa mediaseuranta, hakemus- ja selvitysklinikka - konsultoidaan ja sparrataan järjestöjen toiminta-avustusten tekemistä - sekä tiedon visualisointiin liittyvät palvelut.

Uusia ajattelu- ja toimintamalleja kirjastoissa ovat Lean sekä palvelumuotoilu. Jälkimmäinen on ollut käytössä jo pitkään joissain kirjastoissa, kun taas toisissa käyttö on vasta alkamassa.

Ammatillisesti tärkeää on jatkuva ja yhdessä tapahtuva oppiminen - muuttuvassa maailmassa tarvitaan jatkuvaa uuden opiskelua. Toisaalta tärkeäksi todettiin työpajassa itseohjautuvuus, jolloin kirjastoammattilaisten pitää itse seurata alan kehittymistä ja viestiä sii- hen liittyvistä näkemyksistä ja tarpeista esimiehille ja muulle organisaatiolle.

\section{Kyselyn tulokset}

\section{samansuuntaisia}

dellä kuvatut muutokset kir-
jastoissa ja niiden palveluissa
näkyivät hyvin myös kirjastomän artikkelin alussa. Kyselyn mukaan muutospaine koskee kaikkia kirjastoja, mutta muutoksen luonne vaihtelee eri kirjastosektoreilla: yleisissä kirjastoissa tehtävät laajenevat, korkeakoulukirjastot muuttuvat kehysorganisaatioiden mukana ja erikoiskirjastoissa työnkuvat muuttuvat.

Työpajassa esille tullut kirjastojen epävarmuuden ilmapiiri ilmeni kyselyssä yleisempänä, koko alaa koskevana huolena: $72 \%$ vastaajista oli huolissaan kirjastoalan tulevaisuudesta. Vastaajien mielestä tärkein ominaisuus, jota kirjastoissa työskenteleviltä tulevaisuudessa vaaditaan, on joustavuus muutoksissa. Myös yhteistyö- ja vuorovaikutustaitojen merkitys korostui vastauksissa.

Kirjastoalan kyselyn mukaan kirjaston ammattilaiset tuntevat olevansa ammattitaitoisia ja työssään osaavia. Kuitenkin $80 \%$ vastanneista myöntää uuden osaamisen tarpeen työn ja toimintaympäristön alati muuttuessa.

Kyselyn perusteella alan ammattilaiset toivovat nykyistä enemmän yhteistyötä erilaisten kirjastojen välille 
yhteisten asioiden edistämiseksi. Oivan mahdollisuuden yhteistyöhön ja tiedonvaihtoon tarjoaa liittyminen alan verkostoihin. Kollegojen kesken keskustelut voivat olla hyvin hedelmällisiä ja silmiä avaavia ja osalta osaamisen jakaminen käy luontevasti. Yhteiskunnallisen tiedon kirjastoverkostossa esimerkiksi on keskeisenä toimintatapana yhteinen kouluttautuminen.

\section{Mukaan verkoston} toimintaan?

Kollegojen kohtaamiseen on mahdollisuus alan järjestöjen, yhteisöjen ja verkostojen järjestämissä seminaareissa ja koulutustilaisuuksissa. Näitä pidetään tärkeinä ja niitä kaivataan. Myös kansainväliset tapahtumat ovat hyödyllisiä verkottumiseen ja kokemusten vaihtoon.

Tutustumalla omaa kirjastoaan laa- jempiin ympyröihin osaaminen lisääntyy, mihin esimerkiksi henkilöstövaihto tarjoaa tilaisuuden. Siinä oppii toisen organisaation työmenetelmiä ja voi jakaa hyviä käytäntöjä puolin ja toisin.

Vaikka kirjastot ja toimintaympäristöt vaihtelevat, kirjastoalalla työskenteleviä yhdistää arvopohja, johon ei toivota muutosta: Kirjasto on kaikille avoin, tasa-arvoinen ja saavutettavissa.

Tämän artikkelin pohjana on käytetty Yhteiskunnallisen tiedon kirjastoverkoston työpajan tuloksista tehtyä raporttia, sen kirjoittamiseen osallistuivat allekirjoittaneiden lisäksi Laura Karppinen Tilastokirjastosta, Pia Kilpelänaho YLE Arkistosta sekä Lauri Lehmuskenttä Lastensuojelun keskusliiton kirjastosta.

\section{Lähde}

Kirjasto ammattilaisten silmin.

Kirjastoalan työntekijäselvityksen loppuraportti. Saatavilla: http://suomenkirjastoseura.fi/files/KirjastoalanTy\%C3\%B6ntekij\%C3\%A4tutkimus.pdf

\section{Kirjoittajat}

Mika Holopainen tietoasiantuntija Helsingin yliopiston kirjasto mika.holopainen@helsinki.fi
SirkKa-LiISA KorkeILA tietoasiantuntija Eduskunnan kirjasto sirkka-liisa.korkeila@eduskunta.fi 